\title{
Biofilm Forming Bacteria during Thermal Water Reinjection
}

\author{
Máté Osvald, ${ }^{1}$ Gergely Maróti, ${ }^{2}$ Bernadett Pap, ${ }^{2,3}$ and János Szanyi ${ }^{1}$ \\ ${ }^{1}$ Department of Mineralogy, Geochemistry and Petrology, University of Szeged, Hungary \\ ${ }^{2}$ Institute of Biochemistry, Biological Research Centre, Hungarian Academy of Sciences, Szeged, Hungary \\ ${ }^{3}$ Seqomics Biotechnology Ltd., Mórahalom, Hungary \\ Correspondence should be addressed to Máté Osvald; osimate@geo.u-szeged.hu
}

Received 10 August 2016; Accepted 10 October 2016; Published 9 January 2017

Academic Editor: Francesco Italiano

Copyright (C) 2017 Máté Osvald et al. This is an open access article distributed under the Creative Commons Attribution License, which permits unrestricted use, distribution, and reproduction in any medium, provided the original work is properly cited.

\begin{abstract}
Reinjection of heat-depleted thermal water has long been in the center of scientific interest in Hungary regarding around 1000 operating thermal wells. While the physical and chemical aspects of reinjection have partly been answered in the past years, the effects of biological processes are still less known. We carried out our investigations in the surface elements of the Hódmezővásárhely geothermal system which is one of the oldest operating geothermal systems in Hungary. About one-third of the used geothermal water has been reinjected since 1998 by two reinjection wells at the end of the thermal loops. During the operation, plugging of the surface system was experienced within a few-day-long period, due to biological processes. The goal of our research was to find the dominant species of the microbial flora and to make a proposal to avoid further bacterial problems. We found that the reinjected, therefore the produced, water's chemical oxygen demand, phenol index, and BTEX composition basically determine the appearing flora on the surface. When the concentration of these compounds in the thermal water is significant and residence time is long enough in the buffer tank, certain bacteria can be much more dominant than others, thus able to form a biofilm which plugs the surface equipment much more than it is expected.
\end{abstract}

\section{Introduction}

To cope with humanity's growing energy demands, alternative and renewable energy sources are indispensable. The utilization of geothermal energy is only renewable if the wastewater is reinjected into the reservoir to maintain pressure and to dispose the heat-depleted fluid [1-4]. Reinjection is an essential part when using geothermal energy, however not always trouble-free. In our research two, independent reinjection systems were studied in the Southern part of the Great Plain in Hungary. The motivation of our research was to find out why one of the two reinjection systems' surface filters was clogged much faster.

\section{Background}

From a geological point of view, the Carpathian Basin is a large sedimentary basin, the basement of which consists of variously subsided basins and horst-like blocks. The sedimentary formation environments vary from those from deep basins through prodelta and delta fronts to delta plains [5]. The thickness of Upper Pannonian sediments in the South Great Plain can reach $1800 \mathrm{~m}$ in the MakóHódmezővásárhely depression (Figure 1). This sequence started with a delta front and delta plain facies, which is the most important Upper Pannonian sediment from a hydrogeological point of view, and it followed with a deltaic background and alluvial plain facies. Despite the variable composition, the sedimentary basin system is considered to be hydraulically continuous [6]. The permeability of the Upper Pannonian reservoir, in case of highly permeable sand layers, in the Hódmezővásárhely region can reach $2000 \mathrm{mD}$; this corresponds to a hydraulic conductivity of 5-10 m/day [7].

Hódmezővásárhely, located in the Southern Great Plain of Hungary, has one of the oldest operating geothermal systems in Central Europe (the first well was drilled in 1957), where the cascade system is supplying domestic hot water and heat to 3000 flats and several large communal buildings (city hall, schools, high schools, libraries, swimming pools and sport halls, etc.). The water is also used for medical purposes 


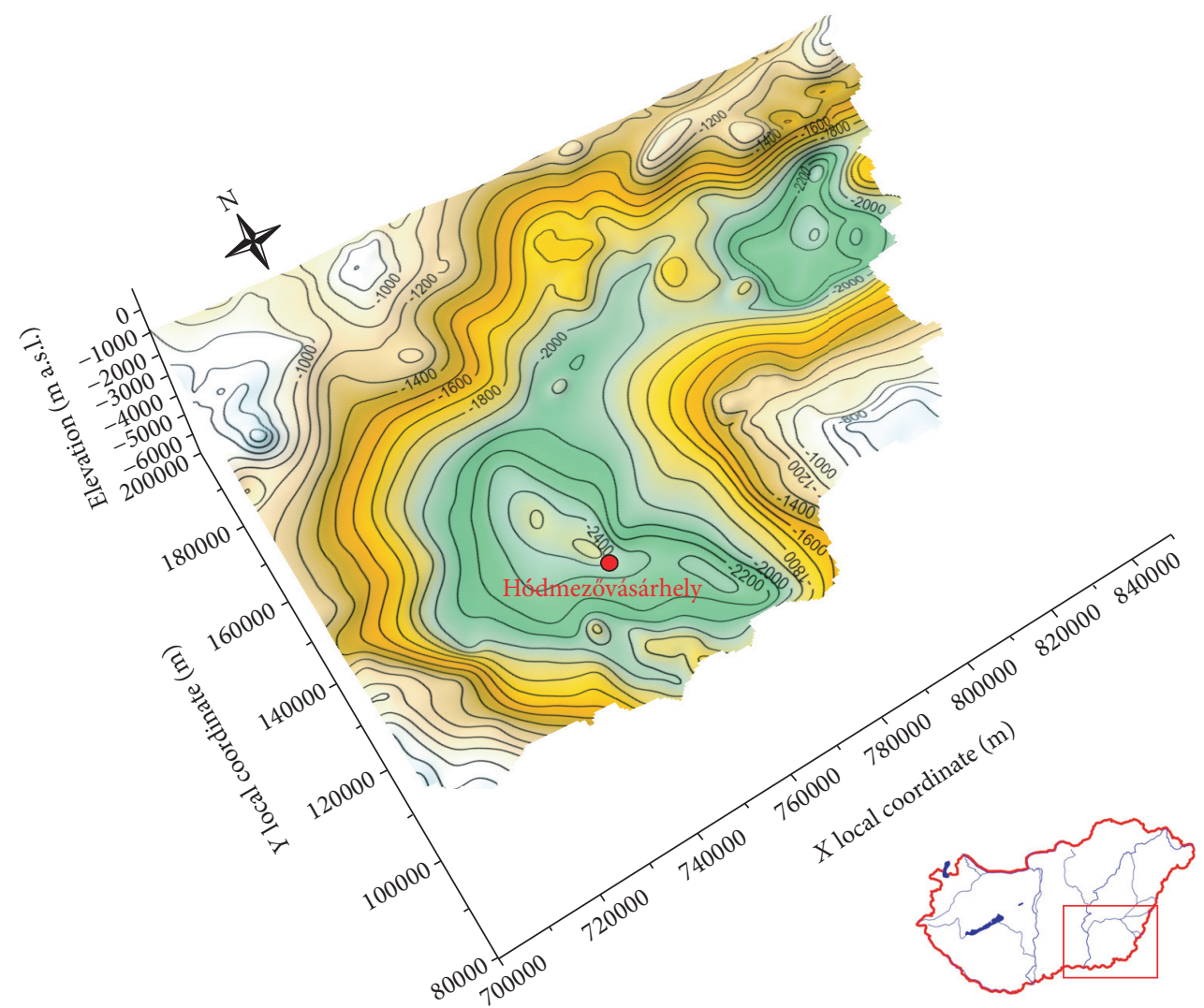

Figure 1: Depth of Upper Pannonian formations in the Southern Great Plain of Hungary.

and balneotherapy at the local spa. The district heating system (that serves the city with almost 50000 inhabitants) is supplied by 3 wells which are producing fluid with 85$90^{\circ} \mathrm{C}$ temperature and are screened between 1800 and $2300 \mathrm{~m}$. The domestic hot water is produced from 2 wells, screened between 1000 and $1300 \mathrm{~m}$, with the temperature of $43-50^{\circ} \mathrm{C}$. In order to maintain the reservoir pressure and to dispose the heat-depleted fluid in an environmentally friendly way, 2 reinjection wells were drilled (Figure 2).

The cascade system in the city comprises two geothermal loops for district heating with the annual production of $350000-420000 \mathrm{~m}^{3}$. About one-third of the used geothermal water has been reinjected since 1998 and additional one-third since 2008 by total two reinjection wells at the end of the thermal loops (Figures 3 and 4) [10].

In our research, two independent reinjection systems were studied as the part of the low temperature geothermal system in the city of Hódmezővásárhely. The surface elements of the reinjection system clogged much faster in case of the reinjection system number 2. According to the well's operator's experience and examination the plugging was not caused by inorganic substances, but organic components were discovered in unusual amount. Changing filters after water with a volume of few hundred $\mathrm{m}^{3}$ flowed through, because of the increased workforce and material need, makes the reinjection costly and decreases the safety of the operation. Therefore, it is important to solve this problem, as the solution would decrease the costs of reinjection, which would guarantee long term sustainability.

To find out what exactly the plugging material is and why does one filter plug one order earlier than the other, samples were taken from the two filters and water samples from any possible locations in the cascade system. Both conservative and modern biological methods were used, which could be used to examine many microbial communities which are not growing during conventional circumstances [11].

\section{Materials and Methods}

3.1. Physical Properties of Each Well. The reinjection well number 1 (B-1094) was drilled in 1998 and is $1685.5 \mathrm{~m}$ deep; the well number 2 (B-1103) was installed in the end of 2007 with $1702 \mathrm{~m}$ depth. The B-1094 reinjection well's injection rate was $30 \mathrm{~m}^{3} / \mathrm{h}$, and the $B-1103$ well's injection rate was $40 \mathrm{~m}^{3} / \mathrm{h}$. The pressure in front of the surface filters was between 2 bar and 6 bar and at the well's head 1.5-4 bar, depending on the filters' saturation. The applied filters were Johnson filter covered with polypropylene fabric with a guaranteed pore size of $30 \mu \mathrm{m}$, but in the practice because of the surface adsorption it could be decreased to $10 \mu \mathrm{m}[10,12]$. It is important to note that the volume of the buffer tank before the reinjection well was $60 \mathrm{~m}^{3}$ in case of well number 1 and $100 \mathrm{~m}^{3}$ in case of well number 2 . During an average heating period, the temperature of water ranged from 27 to $46^{\circ} \mathrm{C}$ and 


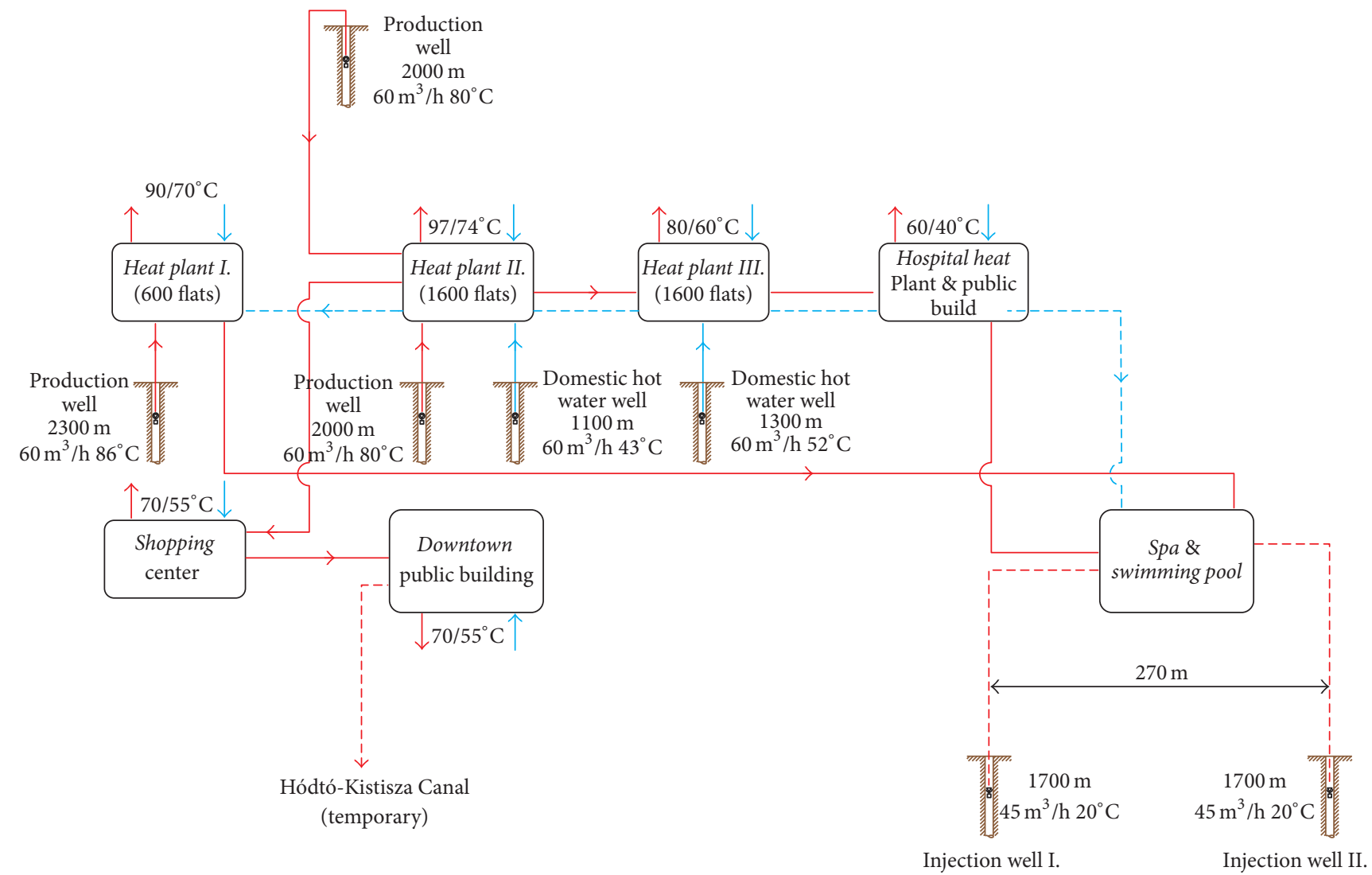

Figure 2: The schematic drawing of the cascade system in Hódmezővásárhely (modified from [8]).

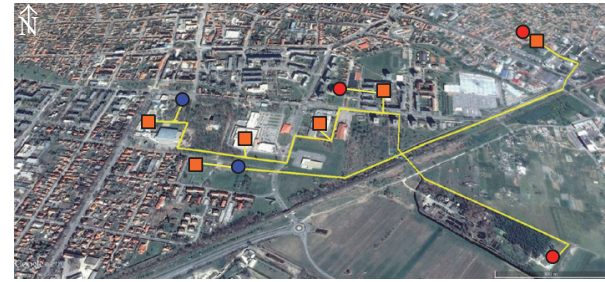

- Production well

- Injection well

口 Heat plant

$\stackrel{300 \mathrm{~m}}{\longleftrightarrow}$

Figure 3: Geothermal cascade system in Hódmezővásárhely.

the replacement of filters was after $2500-5000 \mathrm{~m}^{3}$ fluid flowed through.

The problem occurred during the summertime, when the production was about half of the usual. In this period the reinjection well number 1 was operating at constant capacity; however the reinjection well number 2 was used as a complementary system. As the pump of each injection well only switches on above a certain water level in the buffer tank, the residence time of water in buffer tank 2 increased significantly. During such periods filters of the B-1103 well (filter 2) clogged in three hours after filter changing. In this

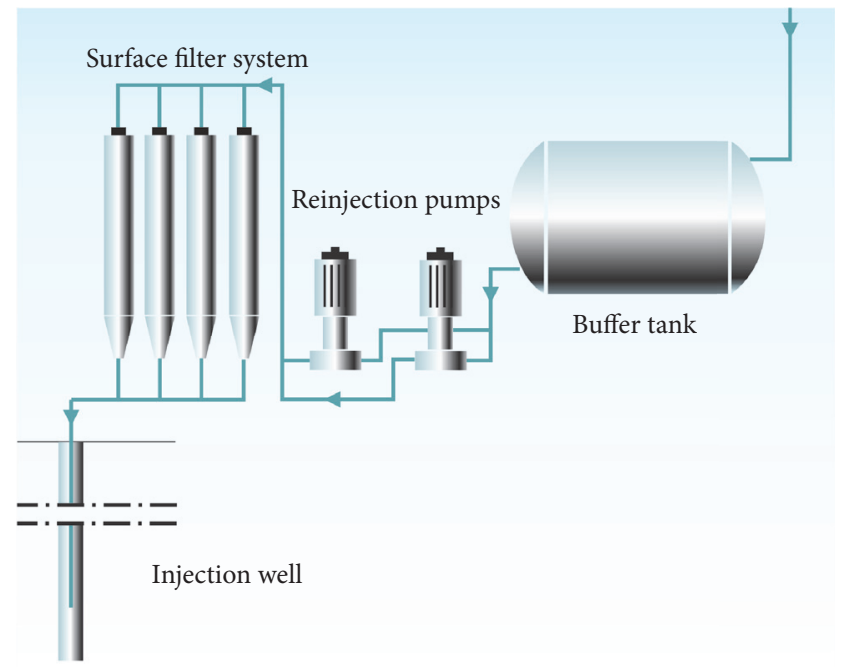

FIGURE 4: The main parts of the thermal water reinjecting system (modified from [9]).

case the temperature of water in the buffer tank was around $34^{\circ} \mathrm{C}$.

3.2. Chemical Composition of the Thermal Water. The concentration of each dissolved component in the water was 
determined as it is stated in the Hungarian Standards, under number MSZ 1484-3:2006. The phenol index measurement was based on the MSZ 1484-1:2009 Standard and the BTEX composition (benzene, toluene, ethylbenzene, and xylene) due to MSZ 1484-4:1998. The measurements were made in accredited laboratory.

3.3. Total DNA Isolation, Sequencing, and Metagenomic Anal$y$ sis. Samples were taken from both filters (of well numbers 1 and 2), the fibers of each filter were loosened with sterile tweezers and with strong shaking the adsorbed materials were washed into water. After centrifugation total DNA was isolated from the sediment according to [13]. The collected samples were extracted with $800 \mu \mathrm{L}$ of extraction buffer (100 mM Tris-HCl, pH 8.0, 100 mMEDTA, pH 8.0, $1.5 \mathrm{M} \mathrm{NaCl}, 100 \mathrm{mM}$ sodium phosphate, $\mathrm{pH} 8.0$, and $1 \%$ CTAB (cetyltrimethylammonium bromide)). After proper mixing $4.3 \mu \mathrm{L}$ of proteinase $\mathrm{K}(20.2 \mathrm{mg} / \mathrm{mL})$ was added. All Eppendorf tubes were incubated horizontally at $37^{\circ} \mathrm{C}$ with shaking for 45 minutes; after that $160 \mu \mathrm{L}$ of $20 \%$ SDS (sodium dodecyl sulfate) was added and mixed by inversion of several times with further incubation at $60^{\circ} \mathrm{C}$ for 1 hour. The samples in each Eppendorf tube were mixed thoroughly after 15 -minute interval. The samples were centrifuged at $13300 \mathrm{rpm}$ for 5 minutes. The supernatant was transferred into new Eppendorf tubes. The remaining pellets were treated with the extraction buffer, as before. After centrifugation the new supernatant was put together with the previous one. All extractions were mixed with equal quantity of phenol : chloroform : isoamyl alcohol (in the ratio of $25: 24: 1$ ) and extracted three times.

Aqueous layer was separated and precipitated with 0.7 (v/v)\% isopropanol (at room temperature). After centrifugation at $13300 \mathrm{rpm}$ for 15 minutes, the DNA pellet was washed with $900 \mu \mathrm{L}$ of $70 \%$ ethanol, dried at $30^{\circ} \mathrm{C}$ in vacuum centrifuge, and was dissolved in $60 \mu \mathrm{L}$ of TE $(10 \mathrm{mM}$ Tris$\mathrm{HCl}, 1 \mathrm{mM}$ EDTA, $\mathrm{pH}$ 8.0). Its quantity was determined in a NanoDrop ND-1000 spectrophotometer (NanoDrop Technologies, Washington, USA). DNA purity was tested by agarose gel electrophoresis. This method yielded a pure (A260/A280 = 1.8) and sufficient amount of total metagenomic DNA. From the DNA samples in vitro fragment library was made according to the protocol of Life Technologies Ion Xpress Plus Fragment Library Kit. The Ion Torrent Personal Genome Machine ${ }^{\mathrm{TM}}$ generated 242,683 and 217,150 reads using Ion 318 chip. The sequence reads were analyzed by the MG-RAST server [14]. By this method, the microbial composition of each filter was determined.

3.4. Localization of the Bacteria's Appearance. Presumably, the higher numbers of bacteria in the second system were able to much faster clog filter 2. We collected thermal water samples from different places of the pipe system of the second reinjection well in order to determine the appearance of the bacteria. The water samples were streaked onto LB agar plates and incubated at $30^{\circ} \mathrm{C}$ under aerobic conditions. Consequently, this method can only be used to obtain approximate results regarding the number of bacteria at certain points of

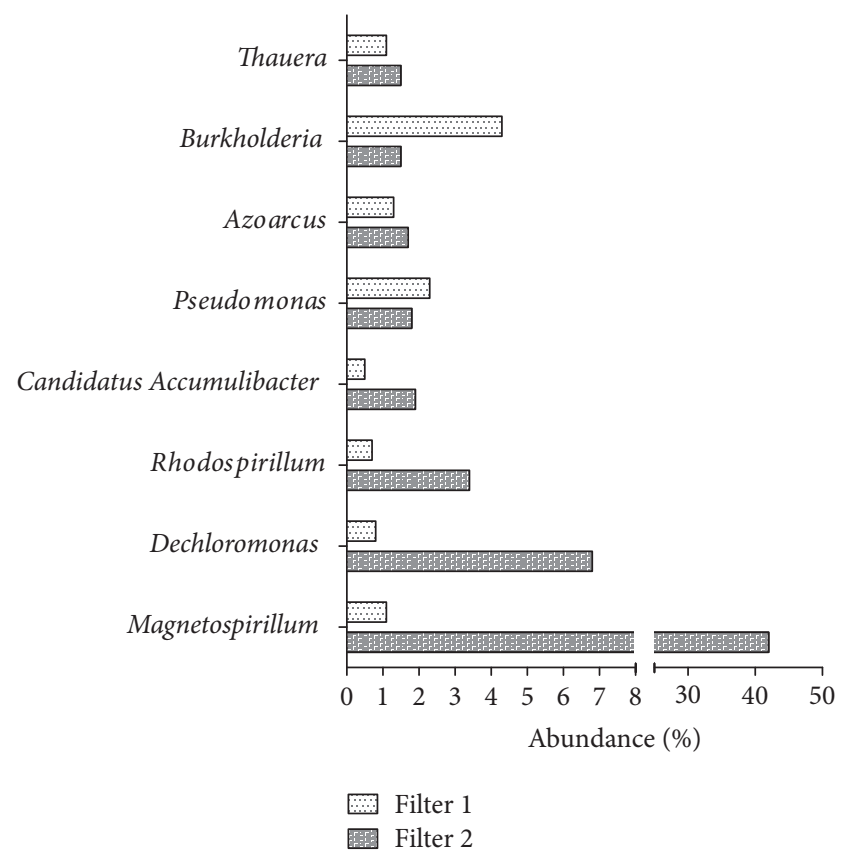

FIgURE 5: The most abundant genera on filter 2 compared to the abundance of the same on filter 1 .

the system that are able to grow under these circumstances [15].

\section{Results and Discussion}

The chemical water analysis showed that the composition of the two wells' water is significantly different. The quickly clogged system's water includes two times more phenol and BTEX compounds than the other system's water and ten times more volatile petroleum hydrocarbon (Table 1) [15]. The high concentration of aromatic compounds may facilitate the overgrowth of aromatic compound degrading bacteria.

According to the results of the metagenomic sequencing, in case of system 1, there were no particularly dominant bacteria species; the dispersion of bacteria is fairly even. The most abundant species on filter 1 were from Erythrobacter (4,9\%), Burkholderia (4,3\%), Methylibium (2,9\%), Pseudomonas (2,9\%), Acidovorax (2,2\%), and Leptothrix (2,2\%) genera. The diversity of bacteria on the filter of the quickly clogged system (number 2) is significantly lower than that of filter 1 [16]. On filter 2, the most dominant genus was Magnetospirillum (42\%). There were also species from the Dechloromonas (6,8\%), Rhodospirillum (3,4\%), Candidatus Accumulibacter (1,9\%), Pseudomonas (1,8\%), Azoarcus (1,7\%), Burkholderia (1,5\%), and Thauera (1,5\%) genera (Figure 5).

Overwhelming occurrence of the Magnetospirillum genus on filter 2 may be surprising; however the sequencing resulted in more than 200,000 good quality reads and the identity of the Magnetospirillum sequences is $99,84 \%$ compared to sequences in the M5RNA database; thus this is a reliable result of the data analysis. 
TABLE 1: Chemical composition of the water at each filter.

\begin{tabular}{|c|c|c|c|}
\hline Component & Unit & Filter 1 & Filter 2 \\
\hline Ammonium & $\mathrm{mg} / \mathrm{L}$ & 11.6 & 13.7 \\
\hline Iron & $\mu \mathrm{g} / \mathrm{L}$ & 121 & 171 \\
\hline Manganese & $\mu \mathrm{g} / \mathrm{L}$ & 4.6 & 5.32 \\
\hline Arsenic & $\mu \mathrm{g} / \mathrm{L}$ & 34 & 42.6 \\
\hline Phenol index & $\mu \mathrm{g} / \mathrm{L}$ & 15 & 2238 \\
\hline Chemical oxygen demand (COD) & $\mathrm{mg} / \mathrm{L}$ & 29 & 120 \\
\hline Extractable hydrocarbons (EPH, C10-C40) & $\mu \mathrm{g} / \mathrm{L}$ & 37 & 34 \\
\hline Volatile petroleum hydrocarbon (VPH, C6-C40) & $\mu \mathrm{g} / \mathrm{L}$ & 16 & 160 \\
\hline Total petroleum hydrocarbon (TPH, C6-C40) & $\mu \mathrm{g} / \mathrm{L}$ & $47<x<53$ & $74<x<84$ \\
\hline Benzene & $\mu \mathrm{g} / \mathrm{L}$ & 0.29 & 14 \\
\hline Toluene & $\mu \mathrm{g} / \mathrm{L}$ & $<0.3$ & 31 \\
\hline Ethylbenzene & $\mu \mathrm{g} / \mathrm{L}$ & $<0.3$ & 13 \\
\hline $\mathrm{m}$ - and p-xylene & $\mu \mathrm{g} / \mathrm{L}$ & $<0.3$ & 19 \\
\hline o-Xylene & $\mu \mathrm{g} / \mathrm{L}$ & $<0.3$ & 8.2 \\
\hline Xylenes & $\mu \mathrm{g} / \mathrm{L}$ & $<0.6$ & 27 \\
\hline Cumene & $\mu \mathrm{g} / \mathrm{L}$ & $<0.3$ & $<0.3$ \\
\hline N-Propylbenzene & $\mu \mathrm{g} / \mathrm{L}$ & $<0.3$ & 0.56 \\
\hline 1,3-Methyl-ethylbenzene & $\mu \mathrm{g} / \mathrm{L}$ & $<0.3$ & 3.5 \\
\hline 1,4-Methyl-ethylbenzene & $\mu \mathrm{g} / \mathrm{L}$ & $<0.3$ & 1.9 \\
\hline 1,3,5-Trimethylbenzene & $\mu \mathrm{g} / \mathrm{L}$ & $<0.3$ & 1.1 \\
\hline 1,2-Methylbenzene & $\mu \mathrm{g} / \mathrm{L}$ & $<0.3$ & 1.4 \\
\hline Tert-butyl-benzene & $\mu \mathrm{g} / \mathrm{L}$ & $<0.3$ & $<0.3$ \\
\hline 1,2,4-Trimethylbenzene & $\mu \mathrm{g} / \mathrm{L}$ & $<0.3$ & 9.8 \\
\hline
\end{tabular}

The members of this group (besides Azoarcus and Thauera genera) are such denitrificans which are able to degrade aromatic compounds [17]. Having magnetosomes (organelles which contain magnetite crystals surrounded by membrane), which are organized into chains and help to orient in geomagnetic field, is also typical of them [18]. Chakraborty et al. showed that Dechloromonas RCB strains are able to break down benzene toluene ethylbenzene and xylene [19]. Members of the Rhodospirillum genus are also capable of using aromatic compounds as food sources [19, 20]. Azoarcus and Thauera genera have the ability to degrade BTEX compounds [21]. Different kinds of aromatic components can be degrading by many members of the Burkholderia genus which makes them suitable for biotechnological applications [22]. Many polycyclic aromatic hydrocarbons(PAHs-) degrading Pseudomonas sp. bacteria have been found to be able to produce biosurfactants [23-25]. Candidatus Accumulibacter populations hydrolyze polyphosphate under anaerobic conditions, while under aerobic conditions they produce polyphosphate which can accumulate in the cells. This process can be utilized for microbiological phosphorous removal from wastewater [26].

Examination of thermal water samples from different points of the second reinjection well system by microbiological test on LB plates revealed the appearance of the bacteria. The test determined that most of the bacteria appeared in the buffer tank and they were also present after the tank, before the filter, but in much smaller quantities.

\section{Conclusions}

The water chemistry analysis showed that the thermal water of the second system is contaminated by phenolic, aromatic, BTEX compounds. Metagenomics revealed the microbial community composition on the filters and found enormous differences between them on the two filters of the two reinjection system. Namely, on filter 2 some bacteria have been found particularly abundant compared to filter 1 . The microbiological test clarified the bacteria appearance in the reinjection well system.

Three different groups of bacteria such as hydrocarbondegrading and biofilm-producing microorganisms (Azoarcus, Leptothrix, Acidovorax, Thauera, Pseudomonas, etc.), $\mathrm{Fe}^{2+}$ - and $\mathrm{Mn}^{2+}$-oxidizing bacteria (Thiobacillus, Sideroxydans, Gallionella, Rhodopseudomonas, etc.), and $\mathrm{Fe}^{3+}-$ and $\mathrm{Mn}^{4+}$-respiring bacteria (Rhodoferax, Geobacter, Magnetospirillum, Sulfurimonas, etc.) were detected by Benedek et al. in a bacterial biofilm, developed on the stainless steel surface of a pump submerged in a gasoline-contaminated hypoxic groundwater [27]. According to [28] iron acquisition may be coupled with $\mathrm{Fe}^{3+}$ reduction, which is needed during intracellular magnetite synthetization. The exact mechanism is unknown [29].

These types of bacteria were mostly inhabited on filter 2 . Likely, the presence of these certain bacteria is responsible for the fast clogging of the filter in case of the second reinjection system. As filter 2 clogged after three hours of the filter 
changing (the sampling from the filters was carried out after three hours), this fact makes it susceptible to believe that this little time is probably not enough for building massive biofilm directly on the filter. From the results of the microbiological test of the thermal water the appearance of the bacteria in the buffer tank was supposed. These bacteria in the buffer tank can be washed out and settle on the filter as a clogging agent. The occurrence of stagnant water zones and a warm $\left(34^{\circ} \mathrm{C}\right)$ used thermal water temperature in a buffer tank create favorable conditions for bacteria to overgrow.

During the year, depending of the demand, the temperature of the reinjected fluid has a large fluctuation. Also, as the samples were taken from the buffer tank, at the recorded temperature, this temperature may be different at various locations of the system. Therefore, it is possible that, due to variance in temperature, in the buffer tank of the reinjection system the circumstances can be optimal for the growth of Magnetospirillum species [30]. These species may also have tolerance to higher temperature, so the temperature is not a very strict limitation parameter [31].

The thermal water contamination (high COD, phenol index, and BTEX) in this low flow area contributes to the feeding and overgrowth of certain bacteria (especially Magnetospirillum sp.). Overgrowth of these bacteria may cause formation of clogging biofilms on the buffer tank surfaces. In spite of the fact that these bacteria have this unfavorable clogging effect on the filters, on the other hand, they can also play a role beneficially in the contaminated thermal water treatment and this property may be exploitable. In the first system the thermal water does not contain such a level of contamination and these extremely abundant bacteria were not detected. It can probably explain why the first reinjection system is free from clogging problems.

Reducing the residence time of the water in the buffer tank and optimizing the size of the buffer tank in order to bypass the stagnant zones, besides disinfecting water in the tank (by UV or ozone), may solve the problem. In the future the water chemistry in the reinjection system designing should be taken into consideration and in case of contaminated water emergence of bacteria can be expected.

\section{Competing Interests}

The authors declare that there is no conflict of interests regarding the publication of this paper.

\section{Acknowledgments}

The authors would like to thank Mihály Kurunczi for funding the chemical analysis and István Nagy for helping each time during sampling.

\section{References}

[1] A. C. Gringarten, "Reservoir lifetime and heat recovery factor in geothermal aquifers used for urban heating," Pure and Applied Geophysics PAGEOPH, vol. 117, no. 1-2, pp. 297-308, 1978.

[2] R. C. M. Malate, "Management of geothermal resources: PNOC-EDC experience," IGC2003-Short Course, Geothermal Training Programme, Reykjavik, Iceland, 2003.
[3] L. Rybach, "Geothermal sustainability", in Proceedings of the European Geothermal Congress 2007, pp. 1-5, Unterhaching, Germany, June 2007.

[4] J. Szanyi, B. Kovács, I. Czinkota et al., "Sustainable geothermal reservoir management using geophysical and hydraulic investigations," in Proceedings of the World Environmental and Water Resources Congress: Bearing Knowledge for Sustainability, pp. 871-875, Palm Springs, Calif, USA, May 2011.

[5] Gy. Juhász, A Szentesi Geotermikus Mező Regionális Geológiai Modellje, Magyar Szénhidrogénipari Kutató-Fejlesztő Intézet, Százhalombatta, Hungary, 1989 (Hungarian).

[6] J. Tóth, "Hydraulic continuity in large sedimentary basins," Hidrológiai Közlöny, vol. 75, no. 3, pp. 153-160, 1995.

[7] J. Szanyi, M. Kurunczi, B. Kóbor, and T. Medgyes, Modern Technologies in Reinjection of Waste-Water, InnoGeo Kft., Szeged, Hungary, 2013 (Hungarian).

[8] J. Szanyi, T. Medgyes, B. Kóbor, and E. Pál-Molnár, Technologies of Injection into Sandstone Reservoirs-Best Practices, Case Studies, GeoLitera Publishing House, Szeged, Hungary, 2015.

[9] M. Kurunczi, “The reinjection,” Introduction of the Geothermal System in Hódmezővásárhely, Proceedings of the Geotermia a XXI, Században Szakmai Fórum Conference, Kistelek, Hungary, 2008.

[10] J. Szanyi and B. Kovács, "Utilization of geothermal systems in South-East Hungary," Geothermics, vol. 39, no. 4, pp. 357-364, 2010.

[11] M. Osvald, Manipulation of lipid content in algae biomass at the blue lagoon R\&D Center [M.S. thesis], Reykjavik University, Reykjavík, Iceland, 2015.

[12] J. Ádók, Hódmezővásárhely’s Geothermal Heating System, FÓKUSZ, Hódmezővásárhely, Hungary, 2014, http://geotermia .lapunk.hu/tarhely/geotermia/dokumentumok/adokjanos_cikk_ hodmezovasarhelyi_geot_fut_rendszer.pdf.

[13] B. Pap, Á. Györkei, I. Z. Boboescu et al., "Temperaturedependent transformation of biogas-producing microbial communities points to the increased importance of hydrogenotrophic methanogenesis under thermophilic operation," Bioresource Technology, vol. 177, pp. 375-380, 2015.

[14] F. Meyer, D. Paarmann, M. D'Souza et al., “The metagenomics RAST server-a public resource for the automatic phylogenetic and functional analysis of metagenomes," BMC Bioinformatics, vol. 9, article 386, 2008.

[15] M. Osvald, Investigation of biological processes in the Hódmezövásárhely geothermal reinjection systems [B.S. thesis], Department of Mineralogy, Geochemistry and Petrology, University of Szeged, Szeged, Hungary, 2014.

[16] I. Czinkota, M. Osvald, J. Szanyi, T. Medgyes, B. Kóbor, and A. Bálint, "Analysis of chemical and biological processes in geothermal systems-a case study," in Proceedings of the World Geothermal Congress, Melbourne, Australia, April 2015.

[17] Y. Shinoda, J. Akagi, Y. Uchihashi et al., "Anaerobic degradation of aromatic compounds by Magnetospirillum strains: isolation and degradation genes," Bioscience, Biotechnology, and Biochemistry, vol. 69, no. 8, pp. 1483-1491, 2005.

[18] D. A. Bazylinski and R. B. Frankel, "Magnetosome formation in prokaryotes," Nature Reviews Microbiology, vol. 2, no. 3, pp. 217-230, 2004

[19] R. Chakraborty, S. M. O'Connor, E. Chan, and J. D. Coates, "Anaerobic degradation of benzene, toluene, ethylbenzene, and xylene compounds by Dechloromonas strain RCB," Applied and Environmental Microbiology, vol. 71, no. 12, pp. 8649-8655, 2005. 
[20] A. A. M. Shoreit and M. S. A. Shabeb, "Utilization of aromatic compounds by phototrophic purple nonsulfur bacteria," Biodegradation, vol. 5, no. 1, pp. 71-76, 1994.

[21] B. Lin, H. W. Van Verseveld, and W. F. M. Röling, "Microbial aspects of anaerobic BTEX degradation," Biomedical and Environmental Sciences, vol. 15, no. 2, pp. 130-144, 2002.

[22] L. A. O'Sullivan and E. Mahenthiralingam, "Biotechnological potential within the genus Burkholderia," Letters in Applied Microbiology, vol. 41, no. 1, pp. 8-11, 2005.

[23] É. Déziel, G. Paquette, R. Villemur, F. Lépine, and J.-G. Bisaillon, "Biosurfactant production by a soil Pseudomonas strain growing on polycyclic aromatic hydrocarbons," Applied and Environmental Microbiology, vol. 62, no. 6, pp. 1908-1912, 1996.

[24] M. Nie, X. Yin, C. Ren, Y. Wang, F. Xu, and Q. Shen, "Novel rhamnolipid biosurfactants produced by a polycyclic aromatic hydrocarbon-degrading bacterium Pseudomonas aeruginosa strain NY3," Biotechnology Advances, vol. 28, no. 5, pp. 635-643, 2010.

[25] W. Xia, Z. Du, Q. Cui et al., "Biosurfactant produced by novel Pseudomonas sp. WJ6 with biodegradation of $n$-alkanes and polycyclic aromatic hydrocarbons," Journal of Hazardous Materials, vol. 276, pp. 489-498, 2014.

[26] L. L. Blackall, G. R. Crocetti, A. M. Saunders, and P. L. Bond, "A review and update of the microbiology of enhanced biological phosphorus removal in wastewater treatment plants," Antonie van Leeuwenhoek, vol. 81, no. 1-4, pp. 681-691, 2002.

[27] T. Benedek, A. Táncsics, I. Szabó et al., "Polyphasic analysis of an Azoarcus-Leptothrix-dominated bacterial biofilm developed on stainless steel surface in a gasoline-contaminated hypoxic groundwater," Environmental Science and Pollution Research, vol. 23, no. 9, pp. 9019-9035, 2016.

[28] D. Schüler, "Formation of magnetosomes in magnetotactic bacteria," Journal of Molecular Microbiology and Biotechnology, vol. 1, no. 1, pp. 79-86, 1999.

[29] L. C. Paoletti and R. P. Blakemore, "Hydroxamate production by Aquaspirillum magnetotacticum," Journal of Bacteriology, vol. 167, no. 1, pp. 73-76, 1986.

[30] C. Moisescu, S. Bonneville, S. Staniland, I. Ardelean, and L. G. Benning, "Iron uptake kinetics and magnetosome formation by Magnetospirillum gryphiswaldense as a function of $\mathrm{pH}$, temperature and dissolved iron availability," Geomicrobiology Journal, vol. 28, no. 7, pp. 590-600, 2011.

[31] E. Katzmann, M. Eibauer, W. Lin, Y. Pan, J. M. Plitzko, and D. Schüler, "Analysis of magnetosome chains in magnetotactic bacteria by magnetic measurements and automated image analysis of electron micrographs," Applied and Environmental Microbiology, vol. 79, no. 24, pp. 7755-7762, 2013. 

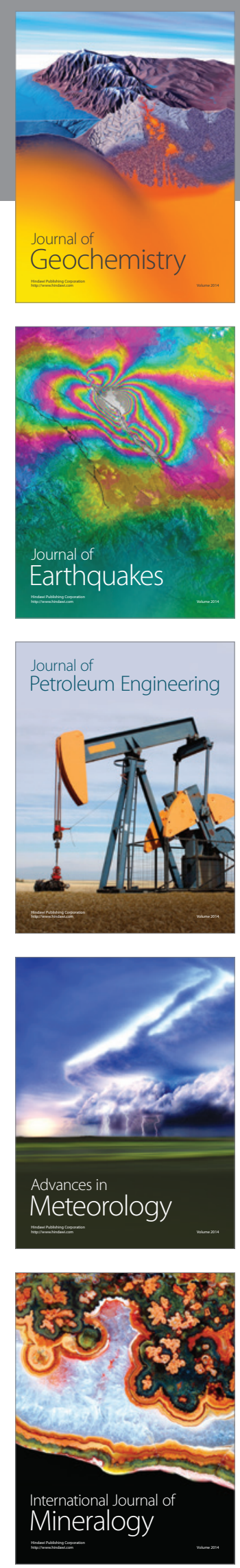
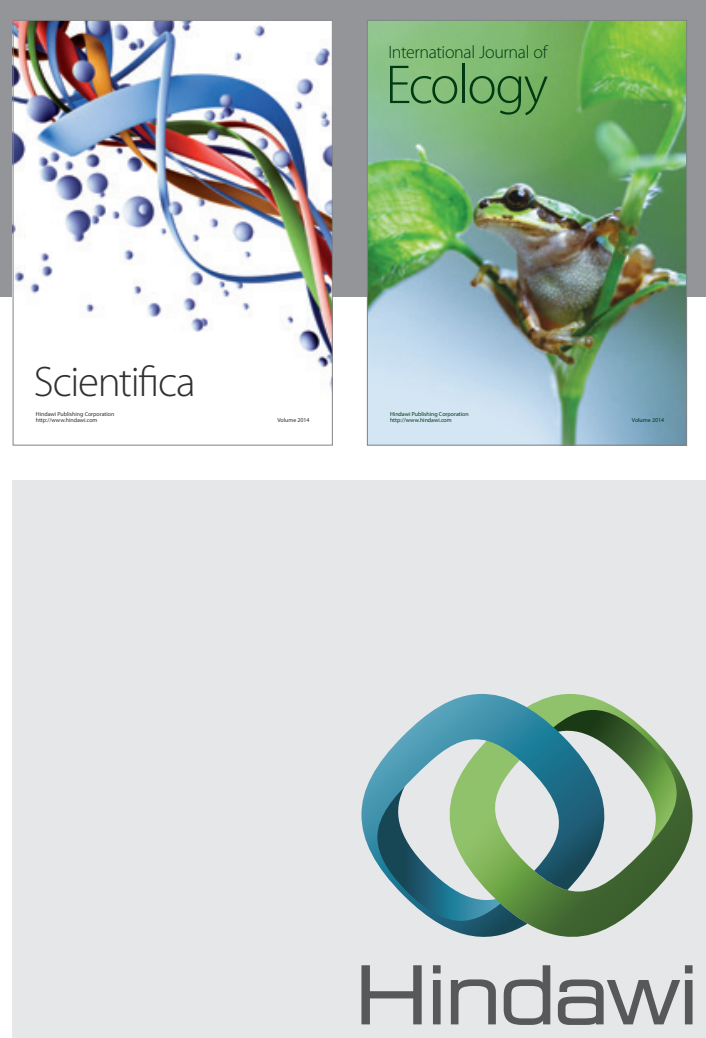

Submit your manuscripts at

https://www.hindawi.com
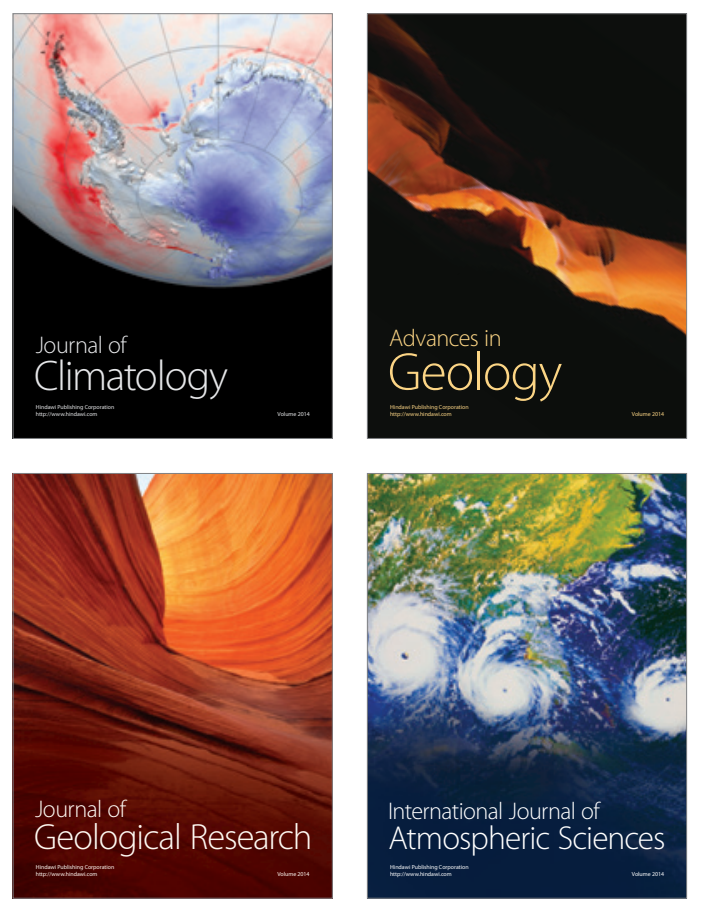

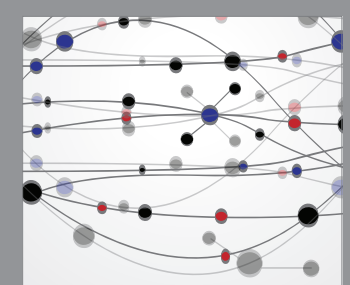

The Scientific

\section{World Journal}
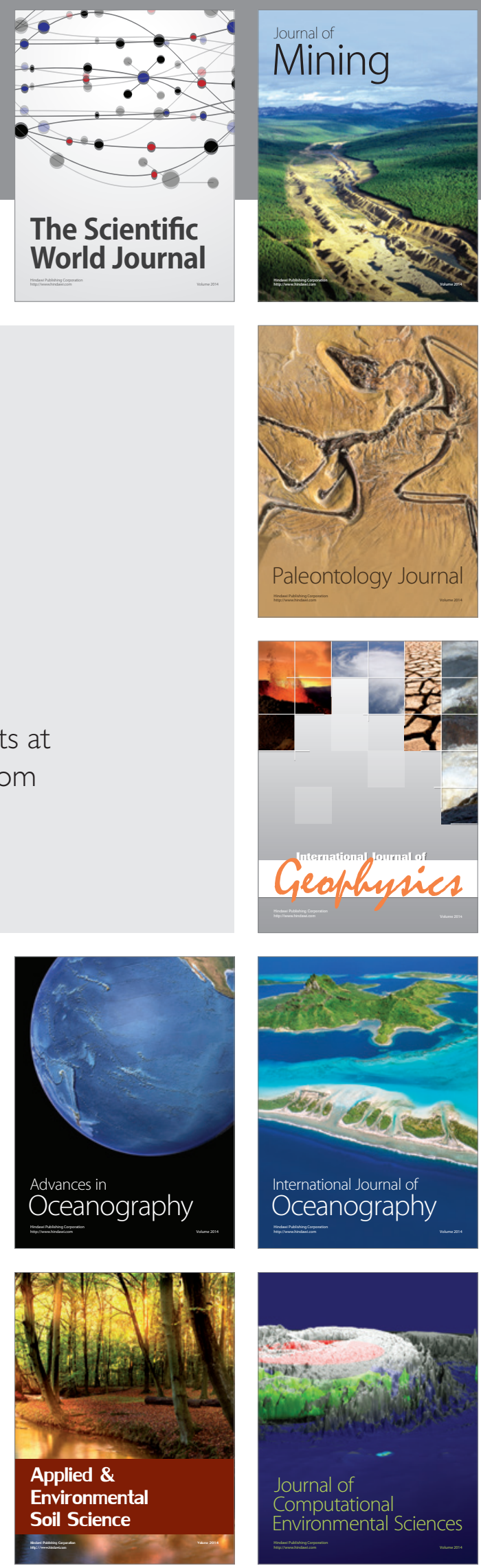